\title{
Developing budgeting and control in throughput accounting system
}

\author{
Sokolov Andrei Yurevich \\ Kazan Federal University \\ Institute of Management, Economic and Finance \\ Kazan, Russia \\ sokolov-kzn@bk.ru
}

\author{
Elsukova Tatyana Vasilevna \\ Kazan Federal University \\ Institute of Management, Economic and Finance \\ Kazan, Russia \\ elsukova.tatyana@gmail.com
}

\author{
Snetkova Tatyana Anatolyevna \\ Kazan Federal University \\ Institute of Management, Economic and Finance \\ Kazan, Russia \\ snetkovat@mail.ru
}

\begin{abstract}
The relevance of the article is the research of topical issues of budgeting costs and results in management accounting on the basis of principles of the theory of constraints. The method "Throughput accounting" is one of the modern developing methods of management accounting in different countries, European and Asian. In the article, the authors observed the lack of theoretical developments and researched the sphere of accounting and costs planning and results on the basis of new theories of management. The authors researched theoretical and methodical questions of the Throughput accounting method, and deeply developed the approach to budgeting of costs and results in the method of management accounting. Budgeting is an important part of the management process at the enterprise, interacting with the management accounting system. The basic results of the research are development of budgets forms: costs and results; examples of drawing up of the costs budget, throughput budget, such as operational costs budget, general variable costs budget and the investment budget in the real production enterprises. Developing budgeting in the throughput accounting system is to be shared with new budgeting methods.
\end{abstract}

Keywords- throughput accounting, budgeting, control, management, costs

\section{INTRODUCTION}

In the method of management accounting, Throughput accounting (method TA), the big role belonged to planning and the control functions. This method of management accounting of costs and results is based on principles of the theory of constraints. According to the theory of constraints, it is necessary to analyze the company's resources, and always one of them will be scarce, and others will be in excess. This resource is for the company limiting, or constraint of production and economic activity. The purpose of the company, according to the theory of constraints is to optimize the business cycle of the company, and therefore increase profits. In the system of management accounting of costs and results TA, planning of the main indicators of costs and results: operating costs, total variable costs (direct material costs) and throughput (revenue minus total variable costs) [1].
The main directions of the theory of constraints methodology in the practice of industrial enterprise management can be used at different levels of planning - from operational and production to the current and strategic planning of the production program [2]. Planning in management accounting at the enterprise should be based on budgeting.

\section{METHODS}

Today, the budgeting system is considered as a necessary element of enterprise management, which should interact with the management accounting system. Therefore, in the budgeting of economic processes in the enterprise it is necessary to use the principles of the theory of constraints. The purpose of this research is a description and practical recommendations on budgeting in this method of management accounting- throughput accounting method.

The author's position on this issue coincides with the position of professor Ivashkevich V. B. [3]. The budget, built on the concept of the theory of constraints, has much more valuable management information:

- first, this budgets expressed a more reliable expected result;

- second, budgets contained measures to optimize the economic process;

- third, budgets are allowed to objectively assess the contribution of each factor of production to the achievement of the final result of economic activity.

Based on the principles of theory of constraints, the authors make the main conclusions for the general methodology of budgeting [4]. First, the budgeting of the economic process should begin with the search, research and planning of the constraint factor. Second, managers should count the calculation of the planned volume of activity, consumed incoming resources and the final result of the activity, considering the maximum capacity of the constraint factor. 
At the same time, one should note that the participation of the provisions of the theory of constraints in the methodology of budgeting the above points is not limited. No less significant results can bring the constraint of the capital budget in the procedure of optimization of the economic process (elimination of existing and search for new constraints). This step involves expanding the throughput capacity of the constraint factor [5].

Next, let us consider the approaches to budgeting revenues and costs, based on the Throughput accounting method. The process of preparation of investment budgets (preparation of long - term costs budget) includes analysis of investment projects with justification of costs and receipt of funds in the future. The management decides how much money to allocate to these projects. Often these projects are the purchases of fixed assets and intangible assets.

\section{RESULTS}

In the Throughput accounting method, priority for funding should be set on any projects that can improve the capacity of a constraint resource, based on a comparison of the increasing additional cost of throughput and the increasing operating costs [6].

Secondly, any investment projects that do not involve a constraint resource, should be subjected to critical analysis and careful selection. Since these projects are not associated with a constraint resource, investments in these projects can not affect the system capacity of the economic process, and therefore, the projects are considered in terms of reducing the operating costs of the enterprise or reduce some of the risks.

Typically, managers review and approve cost budget projects. Some authors provide the following categories of projects [7]:

- projects, associated with the constraint resource,

- projects, associated with risk,

- projects, not associated with a constraint resource. Risk-related projects are projects, that directly affect production at the enterprise, without which there is a risk of production stoppage.

Cost allocation in the budget will be as follows: most of the projects associated with the risk for the existence of the company; the next part of the projects associated with the constraint resource; and the remaining part of the projects not related to the constraint. With the help of capital (investment) budgets, managers rationally implement solutions to increase the productivity of the constraint factor. The budget in table 1 is prepared quarterly in order to be able to distribute the funds evenly throughout the year. Also at the end of the table, we can see the calculation of the increase constraint time after the relevant operations to increase its capacity. According to the preliminary analysis, the constraint factor of management for company "ZPP" is the equipment in the foundry. Therefore, all projects on modernization of old machines, installation of new machines and installation of the conveyor, will be allowed to increase operating time on this resource.
TABLE I. THE INVESTMENT BUDGET OF "ZPP" COMPANY BY THE METHOD OF THROUGHPUT ACCOUNTING IN 2016

\begin{tabular}{|l|l|l|l|l|c|}
\hline \multirow{2}{*}{$\begin{array}{c}\text { Cost of } \\
\text { project, \$. }\end{array}$} & \multicolumn{5}{|c|}{ Cost data } \\
\cline { 2 - 6 } & 1 quarter & 2 quarter & 3 quarter & 4 quarter & Total \\
\hline 1.Projects related to the constraint resource & & & \\
\hline $\begin{array}{l}\text { Additional } \\
\text { machine in the } \\
\text { foundry }\end{array}$ & 250000 & & & \\
\hline $\begin{array}{l}\text { Modernization } \\
\text { of old } \\
\text { machines in } \\
\text { the foundry }\end{array}$ & 180000 & 50000 & & 50000 \\
\hline $\begin{array}{l}\text { Installation of } \\
\text { the conveyor } \\
\text { in the foundry }\end{array}$ & 250000 & 180000 & 50000 & 0 & 480000 \\
\hline Subtotal & & & & \\
\hline 2.Rinyyyyy
\end{tabular}

2.Risk-related projects

\begin{tabular}{|l|l|l|l|l|l|}
\hline $\begin{array}{l}\text { Installation of } \\
\text { water filter in } \\
\text { the plumbing } \\
\text { shop }\end{array}$ & & 380000 & & & \\
\hline $\begin{array}{l}\text { Reduction of } \\
\text { emissions of } \\
\text { asbestos }\end{array}$ & 0 & & 0 & 200000 & 200000 \\
\hline Subtotal & 0 & 380000 & 0 & 200000 & 580000 \\
\hline
\end{tabular}

3.Projects that are not associated with a constraint resource

\begin{tabular}{|l|l|l|l|l|l|}
\hline $\begin{array}{l}\text { Automation of } \\
\text { ceramic } \\
\text { cutting }\end{array}$ & 145000 & & & 145000 \\
\hline $\begin{array}{l}\text { Painting of } \\
\text { buildings of } \\
\text { plant } \\
\text { management }\end{array}$ & 45000 & & & 45000 \\
\hline $\begin{array}{l}\text { Installation of } \\
\text { the conveyor } \\
\text { in the pilot } \\
\text { plant }\end{array}$ & 145000 & 45000 & 80000 & 0 & 270000 \\
\hline $\begin{array}{l}\text { Subtotal } \\
\text { Total }\end{array}$ & 395000 & 605000 & 130000 & 200000 & 1330000 \\
\hline
\end{tabular}

Additional increase in the operating time of the constraint resource, $\min$

Impact on the constraint resource (equipment in the foundry)

\begin{tabular}{|l|l|l|c|c|}
\hline $\begin{array}{l}\text { Additional } \\
\text { machine in the } \\
\text { foundry }\end{array}$ & 360 & 360 & 360 \\
\hline $\begin{array}{l}\text { Modernization } \\
\text { of old } \\
\text { machines in } \\
\text { the foundry }\end{array}$ & & & & 45 \\
\hline $\begin{array}{l}\text { Installation of } \\
\text { the conveyor } \\
\text { in the foundry }\end{array}$ & 0 & 360 & 365,5 & 5,5 \\
\hline Total & & & 5,5 & 410,5 \\
\hline
\end{tabular}


The water filter installation projects and the asbestos abatement project pose a risk to the future operation of the plant if they are not implemented in the planning period. Other projects (automation of cutting of ceramics, conveyor in the shop of pilot production, painting of buildings of the factory management) are not related to the equipment in the foundry, so they are classified in the third category of projects. Then, we are considering the revenue budget (throughput budget). In the methodology TA [8], the main source of information on income is the throughput. Therefore, accountants make throughput budget in the context of products produced by the enterprise and in the context of customers. We calculated this indicator by product in table 2 as the difference between the unit price of the product and the total variable costs per unit. This budget shows how much time is spent by the constraint resource on the production of each product and, in general, it also calculates throughput per unit of time of the constraint resource [9]. This indicator ranks products in an analysis of the production program, as it shows the contribution of each product to the generation of income, taking into account the constraint factor.

TABLE II. THROUGHPUT BUDGET OF "ZPP" COMPANY FOR THE 3RD QUARTER OF 2016 IN TERMS OF PRODUCTS

\begin{tabular}{|l|c|c|c|c|c|c|c|}
\hline \multirow{2}{*}{ Data, \$. } & \multicolumn{5}{|c|}{ Product } & \multicolumn{1}{|c|}{} \\
\cline { 2 - 8 } & $\mathbf{1}$ & $\mathbf{2}$ & $\mathbf{3}$ & $\mathbf{4}$ & $\mathbf{5}$ & $\mathbf{6}$ & Total \\
\hline $\begin{array}{l}\text { Product } \\
\text { quantity, } \\
\text { piece }\end{array}$ & 1200 & 50 & 594 & 200 & 70 & 55 & \\
\hline Price, USD & 510 & 554 & 842 & 777 & 686 & 233 & \\
\hline $\begin{array}{l}\text { Revenue, } \\
\text { USD }\end{array}$ & 612000 & 27700 & 500148 & 155400 & 48020 & 11650 & 1354918 \\
\hline $\begin{array}{l}\text { Total } \\
\text { variable } \\
\text { costs } \\
\text { (TVC), } \\
\text { USD }\end{array}$ & 209 & 250 & 243 & 300 & 280 & 80 & \\
\hline $\begin{array}{l}\text { Throughput } \\
\text { (per prod.), } \\
\text { T }\end{array}$ & 301 & 304 & 599 & 477 & 406 & 153 & \\
\hline $\begin{array}{l}\text { Total } \\
\text { Throughput }\end{array}$ & 361200 & 15200 & 355806 & 95400 & 28420 & 8415 & 864441 \\
\hline $\begin{array}{l}\text { Time of } \\
\text { production } \\
\text { units prod } \\
\text { on the } \\
\text { constraint } \\
\text { resource, } \\
\text { hour, t }\end{array}$ & 0.9 & 2.4 & 0.8 & 1.2 & 1.5 & 1.1 & \\
\hline $\begin{array}{l}\text { Production } \\
\text { Time } \\
\text { cumulative } \\
\text { sales } \\
\text { volume, } \\
\text { hour }\end{array}$ & 1080 & 120 & 475 & 240 & 105 & 60 & 2080 \\
\hline T/t & 334.44 & 126.41 & 749.1 & 398.17 & 271.2 & 139.32 & \\
\hline
\end{tabular}

When managers decide on the introduction of a new product into production, they draw up the throughput budget, taking into account the new product and the time of its production by the constraint resource. Managers make decisions by analysis:

a) throughput product per unit of time constraints (optimization of sales);

b) the need to issue a new product (target sales).
Let us focus on the process of cost budgeting in the management accounting system based on the principles of the theory of constraints (Throughput accounting method). In order to make a total variable costs budget, first, it is necessary to make a budget for each of the components of these costs $[10,11]$. In table 3 we present the total budget variable costs for JSC "RFP" at the end of the third quarter 2016. Variance budget amounted to 22510,75 \$ (increase, mostly on the direct material costs). The next budget we are considering is the revenue budget. In the methodology $\mathrm{TA}$, the main source of information on income is the value of generating cash, so the budget is made the cost of generating cash in the context of the company's products and in the context of customers.

In the Throughput accounting method, all costs other than the total variable costs are attributed to fixed (operating costs) and are not allocated by product type. Next, we consider the operating cost budget (table 4) for the period of the 3rd quarter of 2016, compiled by cost items.

TABLE III. TOTAL VARIABLE COSTS BUDGET OF COMPANY «ZPP» IN THE THROUGHPUT ACCOUNTING SYSTEM

\begin{tabular}{|l|l|l|l|}
\hline \multirow{2}{*}{ Cost item, \$. } & \multicolumn{3}{c|}{ Cost data } \\
\cline { 2 - 4 } & $\begin{array}{c}\text { Plan } \\
\text { (budget })\end{array}$ & \multicolumn{1}{c|}{ Data } & $\begin{array}{c}\text { Deviation } \\
\text { From the } \\
\text { budget }\end{array}$ \\
\hline Direct material costs & 405603,33 & 429114,08 & $(23510,75)$ \\
\hline Sub-contract costs & 56000 & 60000 & $(4000)$ \\
\hline Customs duty & 11354 & 12354 & $(1000)$ \\
\hline $\begin{array}{l}\text { Costs of delivery of the goods } \\
\text { to the buyer, carried out by the } \\
\text { forces of third parties }\end{array}$ & 80000 & 74000 & 6000 \\
\hline Total variable costs & 552957,33 & 575468,08 & $(22510,75)$ \\
\hline
\end{tabular}

Fixed costs are estimated at the responsibility centers, and only a part of them is determined by calculation. The estimated plan has two options:

a) planning based on budgets of previous periods (incremental budget);

b) planning without taking into account the results of previous periods (budget from scratch).

In our case, for operating expenses, we must use the planning, based on budgets of previous periods.

Steven Bragg in his study [7] proposes budgeting operating costs to analyze their significance in relation to the increase in the capacity of the enterprise. Accordingly, we propose operating a budget form as follows (table 4).

This classification of operating costs in the budget reduces those costs that do not affect the increase in the capacity of the enterprise (and, accordingly, the increase of the throughput). Changes in the category of costs associated with the increase in the capacity of the enterprise should be made with a detailed check of their possible impact on the throughput of the company. 
TABLE IV. OPERATING COSTS BUDGET OF COMPANY «ZPP» FOR THE 3RD QUARTER OF 2016 IN THE THROUGHPUT ACCOUNTING SYSTEM

\begin{tabular}{|c|c|c|c|}
\hline \multirow[b]{2}{*}{ Cost item, \$. } & \multicolumn{3}{|c|}{ Cost data } \\
\hline & $\begin{array}{c}\text { Plan } \\
\text { (budget) }\end{array}$ & Data & $\begin{array}{c}\text { Deviation } \\
\text { from the } \\
\text { budget }\end{array}$ \\
\hline \multicolumn{4}{|c|}{ Costs associated with increasing the enterprise capacity } \\
\hline $\begin{array}{l}\text { Direct cost of wages: wages } \\
\text { of production workers }\end{array}$ & 114700 & 120000 & $(5300)$ \\
\hline Indirect costs of raw materials & 7560 & 8950 & $(1390)$ \\
\hline $\begin{array}{l}\text { Indirect costs of wages: wages } \\
\text { of engineers, marketing } \\
\text { department, sales }\end{array}$ & 151000 & 160000 & $(9000)$ \\
\hline Other direct production costs & 32000 & 36500 & $(4500)$ \\
\hline Sales costs & 25000 & 29000 & $(4000)$ \\
\hline Subtotal operating costs & 330260 & 354450 & $(24190)$ \\
\hline \multicolumn{4}{|c|}{ Costs that do not support the enterprise capacity: } \\
\hline $\begin{array}{l}\text { Indirect wage costs: wages of } \\
\text { management personnel }\end{array}$ & 100740 & 100440 & 300 \\
\hline $\begin{array}{l}\text { Other costs for services of } \\
\text { banks, legal services }\end{array}$ & 71000 & 93040 & $(22040)$ \\
\hline $\begin{array}{l}\text { Other costs (travel, business } \\
\text { expenses) }\end{array}$ & 220000 & 227810 & $(7810)$ \\
\hline Subtotal operating costs & 391740 & 421290 & $(29550)$ \\
\hline Total operating costs & 650000 & 675300 & (25300) \\
\hline
\end{tabular}

Operating costs budget (table 4) is based on calculation items. In authors view, it will also be effective to draw up a budget of operating costs in the context of cost items adopted in the management accounting of the organization. It is possible to highlight the following cost elements:

- Operational labor costs of production workers.

- Production operating costs.

- Management operating costs.

- Commercial operating costs.

These items in the budget will coincide with the cost items in the accounts of management accounting, which facilitates the planning and analysis of costs. The cost accounting system, based on the principles of constraint theory, does not allow you to allocate operating costs to product types, but you can distribute them to actions through cost carriers (drivers) to control costs. In this case, it is possible to use the ABA analysis (Activity - based analysis) used in the $A B C$ accounting system. Analysis of costs, in accordance with activity-based costing, will reduce costs not only in places of origin of costs, but also on operations.

Budgeting is only the first stage of the budgeting process at the enterprise. Budgets can be adjusted in connection with the change of economic conditions, according to the results of the year (quarter), when actual cost data are receive. Then, a plan-fact analysis of costs with the identification of deviations from the plan, which is also carried out to identify the causes of deviations and control over the planned indicators. The management control system used information from the management accounting system to maintain financial and nonfinancial performance of the company.

At the moment, budgeting is developing in the direction of "Advanced budgeting" (advanced budgeting), what is considered "improved budgeting" (better budgeting) and "beyond budgeting" (beyond budgeting) [12], which is the development of tools budget -free management.

Budget-free management is a radical approach, the implementation of which at the enterprise requires the involvement and support of the entire management team. Its objectives are more efficient controlling processes, acceleration of planning processes within the existing budgeting system, as well as the transition to "sliding" processes as opposed to a one-time budgeting action, which almost all enterprises undergo once a year. As a result, the adaptability of the enterprise would be significantly increased, as there would be a regular process of internal harmonization and comparison with the dynamics of the external market.

Proponents of the concept of "Improved budgeting" in principle do not question the very tool of traditional budgeting [13]. The main objectives of this approach are to improve efficiency, reduce and simplify planning and budgeting. This evolutionary concept is characterized by constant additional changes, which are carried out in small steps.

"Advanced budgeting" is like "improved budgeting" and "out of budgeting". Despite criticism of traditional planning and budgeting, this tool has proved itself in the past and the complete abandonment of it in the near future seems doubtful. Especially, in terms of requirements for a changed entrepreneurial culture, which tends to be strongly protected from any influences. Therefore, the advanced budgeting approach is aimed at reducing in the medium term the value of budgets, while improving planning quality and reducing resources for budgeting.

Traditional planning and budgeting assumed that the development of the environment can be anticipated and accurately assessed and that the information available to planners makes it possible to make accurate plans. Today such conditions, however, often do not exist, which is due to the reduction of product life cycles and increasing competition. There are a number of external factors that influence business decision-making, and thus planning and budgeting. The most important external factors include complexity — the number and variety of external factors that must be taken into account in the search and decision - making, and dynamics-frequency, regularity and the importance of changing factors.

Given there are stable markets with little complexity and dynamics, detailed planning is impractical because it does not provide important additional information. At the same time, it is enough to compare the "fact-fact" with the involvement of the data of previous years. If the company operates in turbulent markets, it is desirable to plan in detail for a year, plus the average planning time of about four months, which ultimately allows you to estimate the time interval of 16 months as the desired overall planning period. But in practice, this is hardly possible, since the development of events very soon "overtakes" all plans. Dynamic or continuous planning is 
an important tool that is designed to reduce resources in planning and improve planning efficiency.

Every quarter planning is carried out for five quarters. At the same time, it should be borne in mind that only the first quarter of planning is considered in detail, the other four quarters are planned in less detail. Thus, plans for the next four quarters will be reviewed every quarter and a new plan will be drawn up for the fifth quarter. This approach is more time-bound and allows for changes in the external environment. Continuous planning replaces traditional annual planning and periodic calculations of expected results [14].

Integrated planning combines strategic and operational planning. In order to achieve the set strategic goals, measures, so-called strategic actions are defined within the framework of a balanced scorecard. To carry out these activities, each of them was assigned a responsible person; each receives its own budget and they are constantly monitored by controlling activities within the framework of continuous planning.

Budgets "from top to bottom" at the combined level can in principle be sufficient. They should not be kept under constant review. The allocation of budgets for many types of costs, cost centers, combinations of features of the calculation of market segments, etc. is carried out only when it is necessary for business management and is possible from the point of view of common sense.

To really ensure the implementation of the strategy, it is not enough to formulate it only for the general level of the enterprise. The overall balanced scorecard should be extended, taking into account individual contributions to the achievement of the objectives of the enterprise, to all levels of activity without exception and, in certain circumstances, to individual staff [15]. Thanks to the instrument "target agreements", the basis for which are the activities defined within the distribution process the balanced scorecard provides the focus individual action on the strategy, not the operational budget.

Evaluation of results based on established budgetary standards in units directly working with the market is carried out on an erroneous basis, since it does not consider the processes occurring in the environment. Thus, information on the implementation of the plan often leads to hasty and erroneous conclusions, especially if important factors of the external environment are not taken into account. Thus, the increase in turnover compared to the planned $10 \%$ may cause the decision to pay bonuses. But if you pay attention to the fact that at the same time the capacity of the market increased by $25 \%$, and the most important competitor for the same time achieved an increase in turnover by $32 \%$, the success of its sales staff will appear in a completely different light. To get around the problems of absolute planning standards, modern concepts recommend starting from the target on the basis of relative targets, which must be "tied" to the development of important factors of the external environment and which will thus be self-regulating. Interlinked targets and their achievement should be considered within the framework of rolling planning.
It should also be noted that the planning and budgeting process can be improved by using efficient software. Special advantages are promised by the refusal of widespread support in the form of tabular calculation. Experts estimate the share of tabular calculation programs in the total volume of computer-supported planning to be $90-95$ per cent. Compiled with the support of the software continuous, focused on the goals of the integrated strategic and operational planning, taking into account the external environment of the enterprise, forms the basic foundation of progressive planning.

\section{CONCLUSION}

These forms of budgets differ from the classical form of budgets, but retain the basic functions of budgeting - planning and control. The system of management accounting of costs and results, based on the principles of the theory of constraints (method Throughput accounting) allowed managers of enterprises to collect financial and non-financial information to monitor the costs and results of the enterprise, as well as the control of constraint resources in the system, control the level of general variables and operating costs and their deviations from the plan (budget). The use of cost budgeting in the Throughput accounting method will be allowed to optimize the cost structure of the enterprise and determine their impact on the further development of an any company. Thus, for the implementation of the Advanced Budgeting model the following main aspects are taken into account in the enterprises:

- reduction of planning detail (the level of detail depends on the planning area and the market situation);

- continuous rolling forecasting, replacing one-time annual planning;

- sliding strategic planning, which allows you to make adjustments to the strategic plans at the end of a certain time period;

- inclusion of non-financial performance criteria in the operational plan;

- the possibility of choosing a solution within the enterprise business system between short-term profitoriented goals and long-term ones focused on innovative technologies becomes transparent enough for effective enterprise management;

- on the one hand, bringing clear "top-down" goals, on the other, the decentralized nature of current planning;

- use of information systems of planning and efficiency management.

All these aspects will help managers to create an effective budgeting system in the plant enterprises.

\section{Acknowledgment}

The work is performed according to the Russian Government Program of Competitive Growth of Kazan Federal University. 


\section{References}

[1] S. Jackman, "Innovations in Management Accounting Research \& Practice: Whatever happened to Throughput Accounting? " EIASM 6th Conference on new directions in management accounting, Brussels, pp. 25-30, December 2008.

[2] T. Corbett T, Throughput accounting, North river press, 1998.

[3] V.B. Ivashkevich, B.R. Gareev, "Theory of constraints in budgeting systems and value-based management," Upravlencheskii uchet, vol. 8. pp. 98-107, 2009.

[4] A.Y. Sokolov, T.V. Elsukova, "Using ABC to enhance throughput accounting: an integrated management approach," Academy of Strategic Management Journal ,vol. 15, Issue 4, pp. 8-15, 2016.

[5] S. Parkhi, M. Tamraparni, L.Punjabi, "Throughput accounting: An overview and framework," International Journal of Services and Operations Management,vol. 25, Issue 1, pp. 1-20, 2016.

[6] A.Y. Sokolov, Formation of cost information in the system of management accounting, Moscow, Accounting, 2007.

[7] S. M. Bragg, Throughput accounting: guide to constraint management, John Wiley \& Sons, New Jersey, 2007.

[8] M.Yakhou, K. Sulzen, "Changes in budgeting," Corporate Ownership and Control 7(3 E), pp. 465-469, 2010.

[9] D. Kong, "Performance-based budgeting: The U.S. experience," Public Organization Review, vol. 5(2), pp. 91-107, 2005.
[10] A.G. Brink, J.C. Coats, F.W. Rankin, "Who's the boss? The economic and behavioral implications of various characterizations of the superior in participative budgeting research," Journal of Accounting Literature .pp. 89-105, 2018.

[11] P. Prümmer, P. Frey, P. Schentler, H.J. Williams, J. Motwani, "Participative budgeting: A review of empirical research and practical implications," International Journal of Business Innovation and Research, vol.5(5), pp. 559-598, 2011.

[12] B. Popesko, P. Novák, J. Dvorský, Š. Papadaki, "The maturity of a budgeting system and its influence on corporate performance, Acta Polytechnica Hungarica, vol. 14 (7), pp. 91-104, 2017.

[13] S.E. Markaryan, T.A. Snetkova, "Purpose and application peculiarities of management accounting in insurance companies," Mediterranean Journal of Social Sciences, vol.6, Is.1S3, pp. 375-378, 2015.

[14] C. Drury, M. Tayles, "Issues arising from surveys of management accounting practice", Management Accounting Research, 426(3), pp. 267-280, 1995.

[15] B. Ponte, J. Costas, J. Puche,. R. Pino, "The value of lead time reduction and stabilization: A comparison between traditional and collaborative supply chains", Transportation Research, Part E: Logistics and Transportation Review, vol. 111, pp. 165-185, March 2018. 